\title{
Desquamation of Intestinal Epithelium as Indicator of Toxicosis in Fish
}

\author{
Polina Alexandrovna Polistovskaya \\ department of Biochemistry and Physiology \\ FSBEI of higher education Saint-Petersburg state Academy \\ of Veterinary Medicine \\ St. Petersburg, Russia \\ 89111591172@mail.ru
}

\author{
Alesya Aleksandrovna Bakhta \\ department of Biochemistry and Physiology \\ FSBEI of higher education Saint-Petersburg state Academy \\ of Veterinary Medicine \\ St. Petersburg, Russia \\ ab-2003@yandex.ru
}

\author{
Abram Israelovich Enukashvili \\ department of Biochemistry and Physiology \\ FSBEI of higher education Saint-Petersburg state Academy of Veterinary Medicine \\ St. Petersburg, Russia \\ enukashvili@mail.ru
}

\begin{abstract}
This article presents the results of the study of the mechanical strength of the intestinal epithelial layer of carp after exposure to heavy metals (lead, cadmium, zinc and copper). The presence of "live" epithelial cells in intestinal preparations indicates a violation of the mechanical strength of the epithelial layer of the intestine, which, in turn, is a sign of poisoning. 3 series of experiments were carried out: 1) the Effect of 100 limit concentrations of heavy metals in fish, 5 groups of fish (carp) were used: control; group of fish contained in lead acetate $(0.6 \mathrm{mg} / \mathrm{l})$; cadmium acetate $(0.5 \mathrm{mg} / \mathrm{l})$; cupric acetate $(0.1 \mathrm{mg} / \mathrm{l})$; zinc acetate $(10 \mathrm{mg} / \mathrm{l}) ; 2)$ the impact of the 1000 limit concentrations of heavy metals in Fish, used 4 groups of fish (control from the previous series): the fish contained in lead acetate $(6 \mathrm{mg} / \mathrm{l})$; cadmium acetate $(5 \mathrm{mg} / \mathrm{l})$; acetate, copper $(1 \mathrm{mg} / \mathrm{l})$; zinc acetate $(10 \mathrm{mg} / \mathrm{l}) .3)$ the effect of 10000 limit of heavy metal concentration in Fish: 4 groups of fish contained in lead acetate $(60 \mathrm{mg} / \mathrm{l})$; cadmium acetate $(50$ $\mathrm{mg} / \mathrm{l})$; copper acetate $(10 \mathrm{mg} / \mathrm{l})$; zinc acetate $(100 \mathrm{mg} / \mathrm{l})$. The study showed that under the influence of 100 and 1000 limits of copper concentration, there is less mechanical strength of the intestinal epithelium, as well as under the influence of 10,000 limits of cadmium concentration.
\end{abstract}

Keywords - toxic effects, heavy metals, carp.

\section{INTRODUCTION}

Pollution of inland waters by industrial wastewater causes great harm to fisheries in many countries. Industrial poisons, getting into the pond, break the connection of fish with the aquatic environment, affect all stages of the life cycle - from fertilized eggs to mature forms. In addition to the direct toxic effect on fish, they destroy feeding pastures and spawning grounds, complicate, and sometimes make it impossible to migrate fish, cause mass diseases, weakening the overall stability, spoil the commercial quality of fish. In France, England, Belgium, the USA, Germany and other countries, many rivers are poisoned by industrial wastewaters and have lost their fishery importance [6].

The uncontrolled discharge of toxicants into the water bodies leads to a reduction in the food base, loss of fish fry, deterioration and limitation of the hatchability of the fish, migration and reduction of the spawning grounds and as a result to a decrease in the stocks and quality of fish products [15]

The problem of the influence of poisons of industrial wastewater on fishes attracted attention in the mid-nineteenth century, but it still has not received proper theoretical and methodological development both in Russia and abroad. And it is not a lack of experimental data, there are a lot of them. The main reason is the lack of generally accepted principles to carry out the ichtyological experiment: wrong experiments; ignoring non-specific factors of abiotic and biotic nature affect the assessment of the toxicity of various components of industrial wastewater, a variety of criteria of toxicity; the wrong interpretation of experience. As a result, the use of these data for biological regulation of maximum permissible concentrations of industrial wastewater poisons is practically impossible, since in many works the determination of toxicity 
was carried out in short-term experiments by the method of "fish sample". In fact, the development of biological standards for the maximum permissible concentrations of industrial wastewater poisons for fishery water bodies is just beginning and now there are only dozens of substances for which the values of these concentrations are established. This situation is largely due to the lack of due attention to this problem on the part of biologists, the isolation of fish toxicology from General toxicology and the lack of scientific basis for biological regulation of maximum permissible concentrations [6].

Among the pollutants of aquatic ecosystems, heavy metals, including lead, mercury and cadmium, which are particularly toxic, come first.

According to the world Health Organization, heavy metals are now in the second place in terms of their toxic effects. At the same time, experts tend to believe that these toxicants can become more dangerous than nuclear waste and solid waste. Heavy metals enter the body of the fish through the organs of the respiratory and digestive systems [7].

Toxicity of elements for aquatic organisms is sometimes several orders of magnitude higher than for terrestrial animals. In addition, by accumulating in water, sediments and aquatic organisms themselves, heavy metals lead to a decrease in the productivity of aquatic biocenoses and to a potential danger to humans. Once in the body, heavy metals in most cases are not subject to any significant transformations, as it happens with organic toxicants, and included in the biochemical cycle, they are extremely slow to leave it.

Heavy metal ions can form strong bonds in living tissues with various biological active centers, preferably with sulfurcontaining ligands, the sources of which can be low-molecular thiols. They inactivate metal enzymes, disrupting many metabolic processes, change the ratio of blood cells, membrane permeability, inhibit oxidative phosphorylation, protein synthesis, nucleic acids, thereby causing adverse effects on humans [1].

Among heavy metals, lead is one of the most toxic metals. Lead $(\mathrm{Pb})$ is a chemical element of the fourth group, the sixth period of the periodic table (atomic number 82 ), which exists primarily in a bivalent oxidizing form. In natural waters at or above neutral $\mathrm{pH}$, lead easily forms complex compounds. Now lead is used in the production of batteries, and also gets into the water environment from local sources of discharges associated with the production and industrial processing of lead. The bioavailability of lead to aquatic organisms depends on $\mathrm{pH}$, alkalinity, hardness and the content of natural organic matter in water.

In fish, acute toxicity of lead is manifested in the form of respiratory asphyxia with extreme concentrations and violation of the exchange of ions responsible for homeostasis at more environmentally significant concentrations. Chronic effects on fish are similar to those in humans, and they are associated primarily with hematological and neurological dysfunction. Lead is absorbed and exhibits its properties by replacing calcium and other potentially important bivalent cations such as iron and zinc. Accordingly, lead is found mainly within calcined hard tissues of the skeleton and scales, and is concentrated to a large extent in the blood, gills and kidneys. Although much progress has been made in the study of lead uptake, accumulation and toxicity in fish, much more needs to be learned about the routes of entry and transport of lead in the body, as well as the mechanisms of lead excretion [10].

Cadmium $(\mathrm{Cd})$ is an environmental concern. Sources of cadmium in the environment include: rock weathering (e.g. phosphate rock), volcanic activity; and anthropogenic sources associated with the extraction and smelting of zinc, lead and copper ores, the use of phosphate fertilizers, the burning of fossil fuels, peat and wood, and cement production.

Cadmium emissions into the atmosphere can contribute significantly to soil and water pollution, and cadmium itself can be transported over long distances. Cadmium is easily exposed bioaccumulated and bioconcentrated in aquatic organisms. In General, cadmium enters through the gills or through the intestinal tract and then spreads through the blood to other tissues. Cadmium accumulates in almost all tissues and organs, in the liver, kidneys and gills and intestinal epithelium. Acute cadmium toxicity is associated with impaired ion homeostasis, particularly exchange of calcium but also sodium and magnesium. Chronic exposure is also associated with disorders of ionoregulation and disorders of growth, reproduction, immune system, endocrine system, behavior; histopathology of gills, hepatic and renal [3,5].

Unlike gills, the gastrointestinal transport mechanisms of cadmium are not well studied. Absorption of cadmium by the gastrointestinal tract occurs in all parts of the intestine (anterior, middle and posterior), as well as in the stomach [12].

Copper enters into water bodies due to industrial discharges of waste water resulting from the use of fertilizers, having in its composition copper, pesticides [4]. There Are three main forms of copper in water: suspended, colloidal and dissolved. The dissolved form includes free ions and copper compounds in combination with organic and inorganic substances. The amount of copper associated with solid particles can be from 12 to $97 \%$ of its total content in river waters [8]. The soluble forms of copper in uncontaminated fresh water may be contained in the range between 0.5 to $1.0 \mu \mathrm{g} / \mathrm{l}$, while in urban areas this figure may increase to $2 \mathrm{mg} / \mathrm{L}$. The highest concentration is inherent in the mining districts, and subject to flooded areas. The accumulation of copper occurs in all tissues of fish, its highest concentrations in poisoning are observed in the liver [15].

If we talk about its release into the environment, it is associated with the production of waste alloys, galvanized iron and dry galvanic cells. The content of dissolved zinc in unpolluted freshwater systems ranges from 0.5 to $15 \mu \mathrm{g} / \mathrm{L}$. The highest concentrations of this element observed in aqueous systems of industrial areas. Zinc is an active trace element that affects both growth and normal development of organisms $[9,17]$. The toxic properties of zinc are mainly determined by ions, as well as suspension of hydroxide and carbonates.

Symptoms and pathomorphological changes in the poisoning of zinc compounds are similar to those in the poisoning of copper compounds. In acute metal poisoning, there is a darkening of the body color, swelling of the Gills 
petals, hyperplasia and exfoliation of the respiratory epithelium $[2,13]$.

The aim of the study was to study the mechanical strength of the intestinal epithelial layer of carp after exposure to heavy metals: lead, cadmium, zinc and copper.

The study was conducted at the Department of biological chemistry and animal physiology of the St. Petersburg state Academy of Veterinary Medicine in 2017.

In the experiment, was used in common carp (lat.Cyprinus carpio carpio). Three series of experiments were conducted.

In the first series of experiments 5 groups of fish were formed - 1 control group (10 fish), 4 experimental groups -10 fish. All groups of fish were kept at constant aeration of aquariums with a volume of 150 liters. The control group of fish was contained in water without toxic agent; the first experimental group of fish was contained in a solution of lead acetate $\left(\mathrm{Pb}\left(\mathrm{CH}_{3} \mathrm{COO}\right)_{2}\right)$ with a concentration of $0.6 \mathrm{mg} / 1$ (excess of maximum permissible concentration of lead for fishery waters by 100 times) for 4 hours; the second experimental group of fish was contained in a solution of cadmium acetate $\left(\mathrm{Cb}\left(\mathrm{CH}_{3} \mathrm{COO}\right)_{2}\right)$ with a concentration of 0.5 $\mathrm{mg} / \mathrm{l}$ (excess of maximum permissible concentration of cadmium for fishery waters 100 times) for 4 hours; the third experimental group of fish was contained in a solution of copper acetate $\left(\mathrm{Cu}\left(\mathrm{CH}_{3} \mathrm{COO}\right)_{2}\right)$ with a concentration of 0.1 $\mathrm{mg} / \mathrm{l}$ (excess of maximum permissible concentration of copper for fishery waters by 100 times) for 4 hours; 4 the experimental group of fish was contained in a solution of zinc acetate $\left(\mathrm{Zn}\left(\mathrm{CH}_{3} \mathrm{COO}\right)_{2}\right.$ with a concentration of $1 \mathrm{mg} / 1$ (excess of maximum permissible concentration of zinc for fisheries reservoirs in 100 times) for 4 hours. The mechanical strength of the epithelial layer of the carp intestine was studied by preparing a smear - print of the intestine with subsequent staining with hematoxylin and counting the exfoliated living and dead cells using light microscopy in 3 fields of view with an increase of $x 600$.

In the second series of experiments, 4 experimental groups of 10 fish were formed, the control was from the previous series of experiments. All groups of fish were kept at constant aeration of aquariums with a volume of 150 liters. The first experimental group of fish was contained in a solution of lead acetate $\left(\mathrm{Pb}\left(\mathrm{CH}_{3} \mathrm{COO}\right)_{2}\right)$ with a concentration of $6 \mathrm{mg} / 1$ (excess of maximum permissible concentration of lead for fishery water bodies 1000 times) for 4 hours; the second experimental group of fish was contained in a solution of cadmium acetate $(\mathrm{Cb}$ $\left.\left(\mathrm{CH}_{3} \mathrm{COO}\right)_{2}\right)$ with a concentration of $5 \mathrm{mg} / \mathrm{l}$ (excess of maximum permissible concentration of cadmium for fishery water bodies 1000 times) for 4 hours; the third experimental group of fish was contained in a solution of copper acetate $\left(\mathrm{Cu}\left(\mathrm{CH}_{3} \mathrm{COO}\right)_{2}\right)$ with a concentration of $1 \mathrm{mg} / \mathrm{l}$ (excess of maximum permissible concentration of copper for fishery water bodies 1000 times) for 4 hours; the fourth experimental group of fish was contained in a solution of zinc acetate $\left(\mathrm{Zn}\left(\mathrm{CH}_{3} \mathrm{COO}\right)_{2}\right)$ with a concentration of $10 \mathrm{mg} / \mathrm{l}$ (excess of maximum permissible concentration of zinc for fishery water bodies 1000 times) for 4 hours. In this series of experiments, the mechanical strength of the carp intestinal epithelial layer was also studied by preparing a smear-intestinal imprint with subsequent staining with hematoxylin and counting the fused living and dead cells using light microscopy in 3 fields of view with an increase of 600 .

In the third series of experiments, 4 experimental groups of 10 fish were formed, the control was from the previous series of experiments. All groups of fish were kept at constant aeration of aquariums with a volume of 150 liters. The first experimental group of fish was contained in a solution of lead acetate $\left(\mathrm{Pb}\left(\mathrm{CH}_{3} \mathrm{COO}\right)_{2}\right)$ with a concentration of $60 \mathrm{mg} / 1$ (excess of maximum permissible concentration of lead for fishery water bodies 10,000 times) for 4 hours; the second experimental group of fish was contained in a solution of cadmium acetate $\left(\mathrm{Cb}\left(\mathrm{CH}_{3} \mathrm{COO}\right)_{2}\right)$ with a concentration of $50 \mathrm{mg} / 1$ (excess of maximum permissible concentration of cadmium for fishery water bodies 10000 times) for 4 hours; the third experimental group of fish was contained in a solution of copper acetate $\left(\mathrm{Cu}\left(\mathrm{CH}_{3} \mathrm{COO}\right)_{2}\right)$ with a concentration of $10 \mathrm{mg} / \mathrm{l}$ (excess of maximum permissible concentration of copper for fishery water bodies 10,000 times) for 4 hours; the fourth experimental group of fish was contained in a solution of zinc acetate $\left(\mathrm{Zn}\left(\mathrm{CH}_{3} \mathrm{COO}\right)_{2}\right)$ with a concentration of $100 \mathrm{mg} / 1$ (excess of maximum permissible concentration of zinc for fishery water bodies 10,000 times) for 4 hours. In this series of experiments, the mechanical strength of the carp intestinal epithelial layer was also studied by preparing a smear-intestinal imprint with subsequent staining with hematoxylin and counting the fused living and dead cells using light microscopy in 3 fields of view with an increase of 600 .

\section{RESULTS AND DISCUSSION}

When exposed to the body of fish solutions of heavy metals in concentrations exceeding the maximum allowable concentration for fish ponds 100 times, there were observed changes in the behavior of fish, accompanied by inhibition of motor activity and respiratory arrhythmia, as well as a decrease in reflex reactions compared to the control.

Data on the number of cells in the smear-imprint of the intestine of carps after exposure to toxicants with a concentration of 100 maximum permissible concentrations, are presented in Table 1.

When counting cells of the fingerprint of the control sample of the intestine (without the influence of heavy metals), it was noted that the number of "dead" enterocytes corresponded to $89.36 \%$ of the total number of exfoliated cells, while the number of "living" epithelial cells was only $10.64 \%$.

When counting cells in smears - prints of carp intestine after exposure to lead acetate, it was found that the number of "living" cells that retained tinctorial properties is equal to 12.55 $\%$ of the total number of cells. After exposure to cadmium acetate on fish, the number of "living" cells was $14.29 \%$. The number of exfoliated live cells in a smear-imprint after exposure to the toxic solution of acetate of copper amounted to $21.04 \%$, and after exposure in a solution of acetate of zinc $13.11 \%$ of the total number of exfoliated epithelial cells. 
TABLE I. RESULTS OF THE STUDY OF THE IMPACT OF 100 MAXIMUM PERMISSIBLE CONCENTRATIONS OF HEAVY METALS ON THE MECHANICAL STRENGTH OF THE INTESTINAL EPITHELIAL LAYER OF CARP $(\mathrm{M} \pm \mathrm{M})$.

\begin{tabular}{|l|l|l|}
\hline $\begin{array}{l}\text { The concentration of } \\
\text { the toxicant }\end{array}$ & $\begin{array}{l}\text { Number of "dead" } \\
\text { cells (CL.) }\end{array}$ & $\begin{array}{l}\text { Number of "living" } \\
\text { cells (CL.) }\end{array}$ \\
\hline Control $(0 \mathrm{mg} / 1)$ & $22.5 \pm 3.90$ & $2.3 \pm 0.63$ \\
\hline Lead $(0.6 \mathrm{mg} / 1)$ & $124 \pm 12.44^{*}$ & $17.8 \pm 4.08^{*}$ \\
\hline Cadmium $(0.5 \mathrm{mg} / 1)$ & $127.2 \pm 10.53 *$ & $21.2 \pm 3.78^{*}$ \\
\hline Copper $(0.1 \mathrm{mg} / 1)$ & $135.5 \pm 10.22^{*}$ & $36.1 \pm 5.17 *$ \\
\hline Zinc $(1 \mathrm{mg} / 1)$ & $101.4 \pm 8.54 *$ & $15.3 \pm 3.53 *$ \\
\hline
\end{tabular}

According to the data obtained, the most toxic effect on the intestinal epithelium will have copper acetate, less toxic to the intestinal epithelium will be cadmium, then lead, and less toxic of the studied heavy metals will be zinc.

Toxic effects solutions of heavy metals in concentrations exceeding the maximum allowable concentration for fish ponds in 1000 times, on carp showed that the signs of previously detected toxicosis due to exposure to 100 doses of maximum permissible concentrations of toxicants become even more pronounced. Observed inhibition of motor functions of fish (fish freeze on the spot), also there is respiratory failure (Pisces make very frequent the respiratory movements).

Data on the number of cells in the smear-imprint of the intestine of carps after exposure to toxicants with a concentration of 1000 maximum permissible concentrations, are presented in Tabl.2.

TABLE II. RESULTS OF THE STUDY OF THE IMPACT OF 1000 MAXIMUM PERMISSIBLE CONCENTRATIONS OF HEAVY METALS ON THE MECHANICAL STRENGTH OF THE INTESTINAL EPITHELIAL LAYER OF CARP $(\mathrm{M} \pm \mathrm{M})$.

\begin{tabular}{|l|l|l|}
\hline $\begin{array}{l}\text { The concentration of } \\
\text { the toxicant }\end{array}$ & $\begin{array}{l}\text { Number of "dead" } \\
\text { cells (CL.) }\end{array}$ & $\begin{array}{l}\text { Number of "living" } \\
\text { cells (CL.) }\end{array}$ \\
\hline Control $(0 \mathrm{mg} / 1)$ & $22.5 \pm 3.90$ & $2.3 \pm 0.63$ \\
\hline Lead $(6 \mathrm{mg} / 1)$ & $163.9 \pm 10.64^{*}$ & $53.7 \pm 7.57^{*}$ \\
\hline Cadmium (5 mg / 1) & $172.2 \pm 7.96^{*}$ & $55.4 \pm 8.46^{*}$ \\
\hline Copper $(1 \mathrm{mg} / 1)$ & $172.9 \pm 9.05^{*}$ & $61 \pm 8.60^{*}$ \\
\hline Zinc $(10 \mathrm{mg} / 1)$ & $146.3 \pm 10.57^{*}$ & $40.1 \pm 10.84^{*}$ \\
\hline
\end{tabular}

When counting cells in smears - prints of carp intestine after exposure to lead acetate, it was found that the number of "living" cells that retained tinctorial properties is equal to $24.68 \%$ of the total number of cells. After exposure to cadmium acetate on fish, the number of "living" cells was $25.11 \%$. The number of exfoliated live cells in a smear-imprint after exposure to the toxic solution of acetate of copper amounted to $35.28 \%$, and after exposure in a solution of acetate of zinc, $21.51 \%$ of the total number exfoliated in the form of epithelial cells.
Based on the data obtained, the lowest strength will have the intestinal epithelium exposed to copper acetate, cadmium is less toxic to the intestinal epithelium, then - lead, and zinc will be less toxic of the studied heavy metals.

Toxic effects solutions of heavy metals in concentrations exceeding the maximum allowable concentration for fish ponds in 10,000 times,on carp revealed even more pronounced signs of toxicosis. With regard to motor function, the response to higher dose of toxicant opposite the previously observed reactions (some species of fish make sudden fragmentary movement). Insufficiency of respiratory function is present.

Data on the number of cells in the smear-imprint of the intestine of carps after exposure to toxicants with a concentration of 10000 maximum permissible concentrations, are presented in Tabl.3.

When counting the cells in the smears - prints of the carp intestine after exposure to lead acetate, it was found that the number of "living" cells that retained tinctorial properties was $66.97 \%$ of the total number of cells that merged. After exposure to cadmium acetate on fish, the number of "living" cells occurred was $68.59 \%$. The number of exfoliated "live" epithelial cells in the smear-print after exposure to a toxic solution of copper acetate was $67.85 \%$, and after exposure to zinc acetate solution $-65.09 \%$ of the total number of exfoliated epithelial cells.

TABLE III. RESULTS OF THE STUDY OF THE IMPACT OF 10000 MAXIMUM PERMISSIBLE CONCENTRATIONS OF HEAVY METALS ON THE MECHANICAL STRENGTH OF THE INTESTINAL EPITHELIAL LAYER OF CARP $(\mathrm{M} \pm \mathrm{M})$.

\begin{tabular}{|l|l|l|}
\hline $\begin{array}{l}\text { The concentration of } \\
\text { the toxicant }\end{array}$ & $\begin{array}{l}\text { Number of "dead" } \\
\text { cells (CL.) }\end{array}$ & $\begin{array}{l}\text { Number of "living" } \\
\text { cells (CL.) }\end{array}$ \\
\hline Control $(0 \mathrm{mg} / 1)$ & $22.5 \pm 3.90$ & $2.3 \pm 0.63$ \\
\hline Lead $(60 \mathrm{mg} / 1)$ & $83.1 \pm 10,25^{*}$ & $168.5 \pm 13.70^{*}$ \\
\hline Cadmium $(50 \mathrm{mg} / 1)$ & $79.1 \pm 7.65^{*}$ & $172.7 \pm 12.63^{*}$ \\
\hline Copper $(10 \mathrm{mg} / 1)$ & $87.1 \pm 7.28^{*}$ & $183.8 \pm 1213^{*}$ \\
\hline Zinc $(100 \mathrm{mg} / 1)$ & $77.3 \pm 5.74^{*}$ & $144.1 \pm 10.24^{*}$ \\
\hline
\end{tabular}

The data obtained in the study of the effect of heavy metals with a concentration of 10,000 doses of the maximum allowable concentration showed that the lowest strength will have intestinal epithelium exposed to cadmium acetate, less toxic to intestinal epithelium, which will affect copper, then-lead, and zinc will be less toxic of the heavy metals studied.

With the normal functioning of the gastrointestinal tract of fish with their content in an environment without a toxic agent, there is an exfoliation of already obsolete, dead, epithelial cells of the intestine. This process is the norm $[11,16]$.

The presence of the same in the intestinal preparations "live" epithelial cells can be judged on the violation of the strength of the epithelial layer of the intestine of fish, which, in turn, is a sign of poisoning. 
The mechanical strength of the epithelial layer of the intestine is reduced as a consequence of violations not only of the stroma of microvilli of the intestine, but also due to the destruction of intercellular contacts of enterocytes.

Functional damage to the intercellular bonds leads to damage of the structure of the mucous membrane of the small intestine, as a result of which its passive permeability changes and large macromolecules can penetrate into subepithelial tissues, again breaking intercellular bonds.

Desquamation of "living" cells leads to a decrease in the total surface of absorption and absorption capacity, which in turn leads to a disorder of intestinal absorption processes. As a result, the body receives insufficient amounts of hydrolysis products of proteins, fats, carbohydrates, as well as mineral salts and vitamins. Metabolic processes are disrupted. Developing a picture resembling the alimentary dystrophy.

\section{CONCLUSION}

All studied toxicants (zinc, lead, cadmium and copper) under the influence of different concentrations $(100,1000$, 10000 maximum permissible concentrations) have a negative impact on the intestines of fish and on the body of fish as a whole. Studies have shown that high levels (exceeding the maximum allowable concentration of 100,1000 and 10,000 times) in the aquatic environment of heavy metals (zinc, copper, lead and cadmium) can disrupt homeostasis in fish and lead to the development of toxicosis. The indicator of toxicosis can be not only a violation of the behavior, respiratory function of fish, but also a change in the strength of the epithelial layer of the intestine.

In the course of the study, there is a change in the mechanical strength of the epithelial layer of the carp intestine, manifested in the desquamation (exfoliation) of "living" epithelial cells under the influence of certain concentrations of heavy metals (lead, cadmium, zinc, copper). The effect of copper acetate on the strength of the intestinal epithelium of fish exceeds the influence of other studied heavy metals when using toxic solutions of 100 and 1000 maximum permissible concentrations of metal compounds. However, in the study of the effect of toxic solutions of 10.000 maximum permissible concentrations of metal compounds, an increase in the toxicity of cadmium is observed. When exposed to cadmium acetate of the concentration under consideration, the mechanical strength of the carp intestinal epithelial layer is less than that when exposed to copper acetate.

Accumulating in the organs and tissues of fish in quantities exceeding the permissible limits, heavy metals are dangerous for both fish and humans using it for food purposes.

To prevent fish toxicosis, it is necessary to exclude the ingress of heavy metals both into the body of fish and into the reservoirs used for fish breeding, which in turn is achieved by controlling the quality of the feed and water used.

The prospect of further research consists in the possibility of determining the toxic effects on the fish's body before the lethal outcome of the objects under study.

\section{Acknowledgment}

We would like to express our sincere gratitude and thanks to professor of Saint Petersburg state Academy of veterinary medicine, Stopichev Valery Grigorievich, for assistance in conducting this study.

\section{References}

[1] G. K. Budnikov "Heavy metals in environmental monitoring of water systems", Soros, Biology. 1998, Vol. 7, No.5, pp. 23-29.

[2] E. N. Chernova "The content of heavy metals in the bodies of silver carp (CARASSIUS AURATUS GIBELIO) from the reservoirs of southern Primorye", proceedings of the Pacific fisheries research center, 2008, Vol. 154, pp. 214-230.

[3] M. V. Dabagov, E. V. Tabakova, V. I. Titova, Heavy metals: Ecotoxicology and problems of rationing, the Monograph, N. Novgorod: Publishing house VVAGS, 2005, p.165

[4] H. A. Dubov, B. A. Gulidov, A. H. Lapin "Influence of aquatic organisms on the forms of migration of heavy metals in natural water", Ecology. 1991, No.3, pp. 91-93.

[5] N. In. Ivanenko, Environmental toxicology: a tutorial. Vladivostok: Publishing house VGUES, 2006, p. 108

[6] V. I. Lukyanenko, Toxicology of fish, Moscow: Food. prom-St, 1967, p. 216.

[7] A. I. Malarevskaya, F. M. Karasina "Dynamics of the accumulation of heavy metals And total thiamine in fish", 1991, Vol. 27, No.4, pp. 69-74.

[8] P.A. Miller, K.R. Munkittrick, D.G. Dixon "Relationship between concentrations of copper and zinc in water, sediment, benthic invertebrates, and tissues of white sucker (Catostomus commersoni) at metal-contaminated sites", Fish. Aquat. Sci., 1992, Vol. 49, pp. 978-984.

[9] T. I. Moiseenko, L. P. Kudryavtseva, N. Gaskin "Trace elements in surface waters", Moscow: Science, 2006, pp. 115-217.

[10] A. Perlmutter, "Methylmercury/cooper effects on hemosiderin: possible mechanism of immune suppression in fish", Bull. Environ. Contam., Toxicol. 1980, Vol 24, No.5, pp.704-710.

[11] P. A. Polistovskaya, K. P. Kinarevskaya "Effect of cadmium acetate on the body of fish", Proceedings of the international scientific conference of teaching staff, research staff and graduate students of Spbgavm, St. Petersburg, 2018, pp. 77-79.

[12] P. A. Popov, N. In. Androsova, G. N. Anoshin "Accumulation and distribution of heavy and transition metals in fish of the Novosibirsk reservoir", Questions of ichthyology, 2002, Vol. 42, No.2, pp. 264-270.

[13] N. Ah. Rudneva Heavy metals and trace elements in hydrobionts of the Baikal region, Ulan-Ude, 2001, p.136

[14] K. Savvaitova, Y. Chebotova, M. Pichugin, V. Maksimov "The Anomalies in the structure of fish as indicators of the natural environment", Ichthyologies, 1995, Vol. 35, No.2, pp. 182-188.

[15] N.F. Schenone, C. A. Fernandez, L.Vackova "Differential tissue accumulation of arsenic and heavy metals from diets in three edible fish species", Aquaculture nutrition, Vol.20, No.4, 2014, pp. 364-371

[16] V. G. Skopichev, L. Y. Karpenko The physiology of fishes. Book 2. Nutrition and digestion: a study guide, St. Petersburg:The Quadro, 2017 p. 344. 